\title{
Paired-End Sequencing
}

National Cancer Institute

\section{Source}

National Cancer Institute. Paired-End Sequencing. NCI Thesaurus. Code C150423.

A DNA sequencing strategy where a single read is initiated from each end of a DNA fragment. 